\title{
CAESAR AS GOD'S BANKER: \\ USING GERMANY'S CHURCH TAX AS AN EXAMPLE OF NON-GEOGRAPHICALLY BOUNDED TAXING JURISDICTION
}

\section{STEPHANIE HOFFER ${ }^{*}$}

\section{INTRODUCTION}

Germany permits its religious organizations to tax their members. ${ }^{1}$ The tax, which is often collected by the state on behalf of those organizations, is part of the country's constitutionally enshrined tradition of treating its large, lasting religious organizations as public law corporations. ${ }^{2}$ It is a practice that stands directly opposed to the American idea of religious liberty. Nonetheless, it is not as foreign as one might think. Many of the American colonies and the early states levied church taxes that were quite similar to Germany's current system. ${ }^{3}$ The last of these taxes, which supported the churches of Massachusetts, survived until $1833 .^{4}$

Notably, some of the arguments against the German system today are similar to those forwarded by famous voices of the American disestablishment. Despite the obvious dissimilarities of modern Germany and post-colonial America, critics from both periods have argued that church taxes result in undue governmental influence over religious organizations' practices, violate citizens' fundamental right to religious liberty, and are inappropriate in light of increased

* Assistant Professor of Law, The Ohio State University Moritz College of Law. Many thanks to the innumerable colleagues whose hours of conversation and insightful comments have aided me during the creation of this work, not the least of whom are the wonderful Alexander Rust, Andrew Koppelman, Charlotte Crane, Ilan Benshalom, Kenworthey Bilz, Tonja Jacobi, Jide Nzelibe, Philip Postlewaite, Adam Rosenzweig, Miranda Fleisher, Carolyn Jones, Donald Tobin, John Quigley, Amy Cohen, David Perry, and participants of the Third Annual Junior Tax Scholars Conference. I also benefited from the research assistance of Michael Tucker, Jennifer DeVroy, Tonya Major Gauff, Joshua Foote, and wiki master Michael Perez. Last, but not least, thank you to Anne Lorentzen and Brandon Dobyns for their capable assistance in translation. All errors are, of course, my own.

1. See discussion infra Part II.B.1-2.

2. See discussion infra Part II.B.1-2.

3. See discussion infra Part III.

4. See infra note $\mathbf{1 0 3}$ and accompanying text. 
religious diversity. ${ }^{5}$ These shared concerns indicate some level of commonality between the two systems and suggest that the American experience, although antiquated, may hold lessons for those who would reform the German system. But fundamental differences - not the least of which is Germans' ability to avoid the tax by disclaiming membership in the taxing organization-justify retention of the system within German borders. They also serve as a novel starting point for reconsidering geographic boundaries as the denominator of the local taxing power vested in political subdivisions within the United States.

This Article compares the modern-day German church tax to church taxes levied by the American colonies and early states and concludes that, unlike its American counterparts, the German church tax is not wholly a "church" tax. Rather, it is largely a form of decentralized local taxation, the jurisdiction of which is determined by voluntary group affinity rather than geography. As such, it is a crucial part of the German taxing landscape that should not be abandoned but should instead be retained and extended to qualifying secular organizations. In that context-secular rather than sectarian-the tax may also serve as the starting point for developing a model of non-geographically bounded taxing jurisdictions.

Part II of the Article provides a brief description of the history and present state of the German law. Part III, which serves as a point of comparison, focuses on the history and decline of church taxes in the American colonies and early states. It concludes that unexpected

5. See infra notes $81-96,140-43,151-54,166,191-92,199-206$ and accompanying text. For instance, the Nürnberger Zeitung has endorsed a cultural tax born by all taxpayers as a fairer form of support. See Nancy Isenson, Quelling the Flight from the Church (Tax), DEUTSCHE WELLE, Apr. 13, 2004, available at $\mathrm{http} / / \mathrm{www} . \mathrm{dw}$-world.de/dw/article/0,,1168497,00.html. More recently, the debate on entanglement took an interesting turn when a retired religion professor convinced a Freiburg government administrator to allow him to disclaim membership in the Catholic church as a taxing corporation but not as a religion. Melanie Amann \& Lisa Nienhaus, Kirchensteuer: Neun Prozent für das Seelenheil, FRANKFURTER ALlgEMEINE ZEITUNG, Sept. 29, 2009, excerpt translated in Church Tax: Nine Percent for Salvation, CONCORDAT WATCH, available at http://www.concordatwatch.eu/ showkb.php?org_id=1551\&kb_header_id=33981\&kb_id=35601. A court in Freiburg declared the action valid despite opposition from the church, but the decision was later reversed by a court of appeals which held that only the church could decide whether the two are separable. Id. At least one commentator has noted that opposition to the tax arises in part because churches "have turned into omnipresent, profit-oriented social service concerns. Their central function, matters of faith, is thereby neglected." Id. 
de facto cooperation between Evangelical dissenters and Enlightenment thinkers, coupled with increased religious diversity, resulted in a fatal dissatisfaction with the early American church taxes. Part IV of the Article compares the two systems of taxation and concludes that because Germany's system preserves institutional autonomy and is essentially non-mandatory, it adequately addresses the doctrinal concerns raised by Evangelical dissenters during the American disestablishment as well as the concerns of liberty raised by Enlightenment thinkers. Part V observes that although the modern German system preserves organizational autonomy and individual choice, it has not yet responded to the critical challenge of increased religious diversity in German society. A proper response to this development is crucial, because the church tax functions as a local tax that funds a substantial portion of locally provided public goods. ${ }^{6}$ Part VI of the Article concludes that the German system could best account for increasing secularism and religious diversity by conceptualizing the church tax as a means of funding public resources, including religious facilities, rather than as a means solely of supporting religion. Such a re-envisioning of the tax would necessitate greater inclusion of non-religious affinity groups, a possibility which was envisioned by the drafters of the Weimar constitution, ${ }^{7}$ but one which has never been fully realized. Finally, the Article posits that a similar non-geographically bounded taxing jurisdiction, if secularized, could be used to finance the provision of public goods by local governments or non-profit organizations within the United States.

\section{CHURCH TAXES IN GERMANY}

\section{A. A Tumultuous History}

While the church tax in America was essentially an English import, ${ }^{8}$ in Germany, it emerged as a form of governmental

6. See infra notes $260-61$ and accompanying text

7. See infra note 26 .

8. See infra notes $98-100$ and accompanying text. 
compensation for seizures of church property and income during the decline of the Holy Roman Empire. ${ }^{9}$ The empire's destabilization resulted in a lack of centralized governance that facilitated development of independent regional governments at a time when the Reformation was forcibly producing schism within the Christian Church. ${ }^{10}$ Because the church and the government had been inextricably intertwined under the empire, religious schism disrupted not only entrenched belief systems but also basic governance and social support, leaving the Germanic lands in chaos. ${ }^{11}$ Years of fighting ensued, and disorder allowed various regional rulers to seize ecclesiastical lands and other property, depriving churches of some of their traditional means of support. ${ }^{12}$ An uneasy compromise emerged in the Religious Peace of Augsburg: with the pronouncement of "cuius regio, euis religio," the ruler of each region became responsible for selecting and ensuring financial support for that region's religious affiliation. ${ }^{13}$ The resulting mix of sects persisted throughout Prussian unification and made Germany unique among the European nations. ${ }^{14}$

9. In Germany, the Catholic Church was a powerful landholder during the years of the empire. Because the Church was essentially a sectarian head of government, the emperor relied on church officials for administration, which was naturally uncomfortable for both sides. The inevitable tension between secular and sectarian interests eventually led to violence, and the Church unceremoniously dethroned the ruling family of the day. In doing so, it necessarily stabbed at its own cohesion at a critical time in its own history, the years preceding the Reformation. Jan Deutsch, Some Problems of Church and State in the Weimar Constitution, 72 YALE L.J. 457, 457-58 (1963).

In contrast, the church tax in the colonies arose from two sources: the Puritan experiment with theocracy in New England, and the establishment of the Church of England in Virginia and the surrounding colonies. See D. B. Robertson, Should Churches BE TAXed? 44-45 (The Westminster Press 1968).

10. Deutsch, supra note 9, at 458. See also Gerhard Robbers, State and Church in Germany, in STATE AND CHURCH IN THE EUROPEAN UNION 57 (Gerhard Robbers ed., Nomos Verlagsgesellschaft 1996). The truce produced a recognition of the Catholic and Lutheran churches as "essentially equal." Id. at 58 .

11. Robbers, supra note 10.

12. Roger Wells, The Financial Relations of Church and State in Germany 1919-1937, 53 PoL. SCI. Q. 36, 39 (1938).

13. Reinhard Henkel, State-Church Relationships in Germany: Past and Present, 67 GEoJolrNaL 307, 308 (2006). A similar principle is embodied in the Treaty of Westphalia, which ended the Thirty Years' War. Id.

14. Deutsch, supra note 9 , at $\mathbf{4 5 8}$. Germany remained relatively diverse with regard to religion, and despite General Bismarck's Kulturkampf against the Catholic Church, the sectarian mix among regions persisted through the First World War. Id.; see also Henkel, supra note 13, at 309. 
As time passed, the populations of towns and cities increased, which led to the creation of new urban congregations. ${ }^{15}$ Agricultural and productions tithes, which were traditionally administered by the church, became less relevant in the changing society. They were taken over by the state and eventually abolished. ${ }^{16}$ Regional governments were then faced with the problem of funding their churches in an increasingly industrial, trade-based economy. ${ }^{17}$ Like all governments in need of revenue, the regional governments of Germany turned to taxes for a solution. The principality of Lippe was the first region to institute a church tax, and over time, the idea spread to other regional governments. ${ }^{18}$ In its original iteration, the tax was levied by municipalities against their residents. ${ }^{19}$ Later, churches gained the power to levy the tax, but local governments retained the power of collection. ${ }^{20}$

\section{B. German Church Tax in Modernity}

\section{Constitutional Basis for the Tax}

Although its roots are historically much deeper, the first federal codification of the church tax appeared after World War I in the Weimarer Reichsverfassung, the constitution of the Weimar Republic. ${ }^{21}$ The document was the result of a compromise between the Catholic-supported Center Party and the Social Democrats who favored strict separation. ${ }^{22}$ It recognized the importance of religion in Germany's social fabric while acknowledging the necessity of

15. Christine R. Barker, Church and State Relationships in German "Public Benefit" Law, 3 INT'L J. OF NOT-FOR-PROFIT L. pt. V (2000), available at http://www.icnl.org/knowledge/ijnl/vol3iss2/ art_l.htm.

16. Wells, supra note 12 , at 43 . These tithes generally required producers of agricultural goods and trade wares to transfer approximately one-tenth of their production output to the church. See Barker, supra note 15 , pt. V.

17. See Barker, supra note 15 , pt. V.

18. Wells, supra note 12, at 43. Lippe is located in the northeastern portion of modern-day North Rhine-Westphalia. The tax was adopted by Lippe in 1827 , by Oldenburg in 1831 , by SachsenAltenburg in 1837 , and by Saxony in 1838 . Id.; see also Barker, supra note 15 , pt. V.

19. Wells, supra note 12 , at 43 .

20. Id.

21. See WEIMARER REICHSVERFASSUNG art. 137.

22. Deutsch, supra note 9, at 460; see also WEIMARER REICHSVERFASSUNG arts. 136-137. 
religious freedom in a modern democracy. ${ }^{23}$ It guaranteed that political and civil rights would be afforded to citizens regardless of their religious affiliation and that no citizen would be bound to disclose his religious convictions to the government. ${ }^{24}$ It also guaranteed freedom of association for religious groups. ${ }^{25}$ In addition, at the behest of the Social Democrats, the constitution placed organizations that espouse a world philosophy on equal footing with traditional organizations that worship a deity. ${ }^{26}$ Finally, and most significantly, the Weimar constitution provided that religious bodies and world view organizations were entitled to seek status as public law corporations with a specifically enumerated right to tax their members. ${ }^{27}$ In short, while the constitution abolished state supervision of religious organizations, it did not forbid cooperation between church and state when the two organizations pursue a common goal, such as the provision of public goods and services.

Although this obvious entanglement was strained under the Third Reich, it was not broken, and the church tax persisted in law if not in practice. $^{28}$ Following World War II, the Grundgesetz, or 137.

24. WEIMARER REICHSVERFASSUNG art. 136.

25. Id. art. 137.

26. Id. art. 137; see Deutsch, supra note 9, at 464 (Social Democrats ensured that organizations devoted to systems of ethics were accorded the same constitutional privileges as religious organizations). Like Germany's pre-war principalities, its post-war constitutional assembly was far from unified. Weimar's Enlightenment leaders were forced to rely on the support of the Center Party, which was primarily Catholic, when crafting what was essentially a coalition constitution. See Deutsch, supra note 9 , at 460 . As a result, a constitution which otherwise might have called for strict separation of church and state now permits a level of government/state interaction that United States jurists would find astonishing. See Deutsch, supra note 9, at 463.

27. WEIMARER REICHSVERFASSUNG art. 137; see Deutsch, supra note 9, at 464 .

28. The National Socialists replaced Weimar's federal system with a more highly centralized form of government, and they made an unsuccessful attempt to nationalize the Evangelical Lutheran Church. Wells, supra note 12, at 51-54. The effort produced a schism in the church's leadership, with pro- and anti-government leaders both claiming to represent the true way. $I d$. at 51 . The religious schism gave rise to a governmental dispute not over whether the church should be funded, but instead over who should receive the funds. $I d$. at 55 . The country's new leadership was openly frustrated by the church's infighting. Reich Minister of the Interior Frick intimated that the government might strip the Evangelical Church of its status as a public law corporation, and Reich Minister of Propaganda Goebbels publicly stated that the government might withdraw its support from the church. Id. Almost unbelievably, the issue was delegated to a special tribunal, which took over two years to address the matter. $I d$. at $52-53$. In the midst of the war, the government was forced to abandon the question and, 
constitution, of the Federal Republic of Germany (West Germany) incorporated the Weimarer Reichsverfassung's articles on religion by reference and made them fully applicable to the new western democracy. ${ }^{29}$ The situation in the German Democratic Republic (East Germany), however, was vastly different. ${ }^{30}$ Although church membership was nominally tolerated, it was discouraged. ${ }^{31}$ Church members were highly disfavored by the communist government and were denied many of the benefits of East German citizenship, such as they were. ${ }^{32}$ As a consequence of the state's position, very few people maintained a religious affiliation. ${ }^{33}$ East Germany later acceded to the Grundgesetz by signing the Unification Treaty in 1990, once again rendering Weimar's articles on religion applicable to the whole of the country. ${ }^{34}$ By that time, however, the East German state's actions had drastically reduced churches' membership rolls. ${ }^{35}$ As a consequence, the church tax now generates very little revenue in the formerly communist states. ${ }^{36}$

\section{Today's Church Tax in Practice}

Today, the Grundgesetz provides that there shall be no state church in Germany. ${ }^{37}$ Nonetheless, religious organizations that were

fortunately, never received the opportunity to revisit it. In light of everything else that was happening, the tax proved to be remarkably hardy.

29. Grundgesetz für die Bundesrepublik Deutschland [GG] [Constitution] art. 140.

30. See Barker, supra note 15 , pt. VI.

31. See John S. Conway, The "Stasi" and the Churches: Between Coercion and Compromise in East German Protestantism, 1949-89, 36 J. CHURCH \& ST. 725, 727-31 (1994).

32. Id. In addition, the East German state replaced religious confirmation services with a communist youth initiation ceremony called the "Jugendweihe." Remarkably, this practice has taken hold in the East and continues to this day. Barker, supra note 15, pt. VI.

33. Barker, supra note 15 , pt. VI.

34. See Treaty between the Federal Republic of Germany and the German Democratic Republic on the Establishment of German Unity (Unification Treaty), F.R.G.-G.D.R., Aug. 31, 1990, available at http://bundesrecht.juris.de/einigvtr/BJNR208890990.

35. At the time of the reunification, it was estimated that only $2-3 \%$ of the population still participated in religious services. Conway, supra note 31 , at 742 .

36. Only $5-10 \%$ of citizens in the former East Germany are affiliated with religious organizations. U.S. DEP'T OF STATE, GERMANY INTERNATIONAL RELIGIOUS FREEDOM REPORT 2008, available at http://www.state.gov/g/drl/rls/irf/2008/108448.htm [hereinafter RELIGIOUS FREEDOM REPORT].

37. Article 140 of the Grundgesetz provides that Article 137 of the Weimar Constitution shall be incorporated by reference. GG art. 140 . Article 137 provides that there shall be no state church. GG art. 137. 
corporations under public law at the time of its adoption remain so, and new organizations may apply for the status. ${ }^{38}$ This status of public law corporation confers a number of important rights, including the right to employ clergy and other administrators as civil servants in the military, in hospitals, in universities, and in other public facilities. ${ }^{39}$ In addition, public law corporations are exempt from bankruptcy laws, ${ }^{40}$ corporate income tax, and inheritance and gift taxes. ${ }^{41}$ Representatives of religious organizations with public law corporation status have the right to participate on public boards, such as the supervisory boards of public and private broadcasting stations as well as boards that review films and literature for suitability. ${ }^{42}$ Public law corporations are also entitled to draft ordinances applicable to their members for the governance of the organization. ${ }^{43}$ These internal legal systems, "which operate in parallel with public laws," can be striking in their complexity, and decisions rendered within them fall outside of the jurisdiction of Germany's courts. ${ }^{44}$ Finally, and importantly, religious organizations that are public law corporations have recourse to the church tax. ${ }^{45}$

The Grundgesetz provides that a state must grant public law corporation status to any requesting organization whose constitution and number of members ensure permanency. ${ }^{46}$ In addition, a religious organization must show that it is not hostile to the constitutional order or to fundamental rights. ${ }^{47}$ This rule, enunciated

38. See WEIMARER REICHSVERFASSUNG art. 137.

39. Barker, supra note 15, pt. I; see also WEIMARER REICHSVERFASSUNG arts. 137, 140.

40. Gerhard Robbers, Minority Churches in Germany, LEGAL STATUS OF RELIGIOUS MiNORITIES IN THE COUNTRIES OF THE EUROPEAN UNION: PROCEEDINGS OF THE MEETING THESSALONIKI 153, 159 (Nov. 19-20, 1993) [hereinafter Robbers, Minority Churches].

41. See Körperschaftsteuergesetz [KStG] [Corporate Tax Act], repromulgated Oct. 15, 2002, BGB1. I at 4144, last amended by Gesetz, Apr. 8, 2010, BGBl. I at 386, $§ 5(1)(9)$; Erbschaftsteuer- und Schenkungsteuergesetz [ErbStG] [Inheritance and Gift Tax Act] $\S 13(1)(16)$. Abgabenordnung [AO] [Tax Act], repromulgated Feb. 27, 2007, BGBI. I at 378, last amended by Gesetz, Dec. 22, 2009 BGBI. I at 3950, $\S 13(1)(6) ;$ Abgabenordnung [AO] [Tax Act], repromulgated Oct. 1, 2002, BGBl. I at 3866, $\S \S 51-68$ (describing some of the qualifications that organizations must meet to obtain exempt status).

42. Robbers, Minority Churches, supra note 40, at 169.

43. See Robbers, supra note 10 , at $62-64$.

44. See id.

45. See WEIMARER REICHSVERFASSUNG art. 137; GG art. 140.

46. GG art. 140 .

47. See Bundesverfassungsgericht [BverFG] [Federal Constitutional Court] Dec. 19, 2000, 102 Entscheidungen des Bundesverfassungsgerichts [BVerfGE] 370, 392; see also RELIGIOUS FREEDOM 
in a recent case by the Bundesverfassungsgericht, which is the court of final jurisdiction for German constitutional questions, ${ }^{48}$ is intended to safeguard the limited partnership between the government and religious corporations envisioned by the constitution. ${ }^{49}$ As the high court noted, the constitution does not require fidelity from all religious organizations; however, those seeking partnership with the government through public law corporate status must show that they are not inimical to the values espoused by the Grundgesetz. ${ }^{50}$ The court solidified its position by observing that public law corporation status is no empty form: among other things, the court noted, it confers the capacity to employ civil servants and to levy taxes. ${ }^{51}$ These, the court wrote, are clear indicia of a measure of transferred sovereignty. ${ }^{52}$ It is natural that the government would not share its sovereignty with an organization that would seek to undermine it outside of constitutionally-permitted channels; thus, organizations seeking public law status must not seek to upset the constitutional order.

All religious organizations that pass the court's constitutional test are entitled to levy taxes against their members on the basis of the civil tax rolls in accordance with provisions of the states' laws. ${ }^{53}$ The two largest beneficiaries of the statutes are the Catholic and Evangelical churches. ${ }^{54}$ Although Germany does not keep official statistics on religious groups, it is estimated that of Germany's approximately 82 million citizens, roughly 25.7 million are Catholic and roughly 25.3 million are Evangelical. ${ }^{55}$ These groups, both of

REPORT, supra note 36; Thilo Marauhn, Status, Rights and Obligations of Religious Communities in a Human Rights Context: A European Perspective, 34 ISR. L. REV. 600, 633 (2000).

48. 102 BVerfGE at 392-97; GG art. 1 para. 3; see also Bundesverfassungsgerichtsgesetz [Law on the Federal Constitutional Court], Mar. 12, 1951, BGB1. I at 243, last amended by Gesetz art. 2, Dec. 1, 2009, BGB1. I at 3822, $\$ 113-14$.

49. 102 BVerfGE at 392-97.

50. Id. at 392 .

51. Id. at 371 .

52. Id. at 388 .

53. Id. at 388-90.

54. See Robbers, supra note 10 , at 57.

55. See RELIGIOUS FREEDOM REPORT, supra note 36; see also Robbers, supra note 10, at 57 (in 1991, there were an estimated 28.2 million Catholics and 29.2 Evangelicals). It is worth noting that the church-going populace is located substantially in West Germany. It is estimated that only between 5\% and $10 \%$ of the populace of former East Germany are church members. RELIGIOUS FREEDOM REPORT, supra note 36 . 
which pay the church tax, comprise roughly two-thirds of Germany's population. ${ }^{56}$ A number of smaller groups also qualify as public law corporations. For instance, Jewish synagogues, the Salvation Army, the Latter Day Saints, and the German Humanist Association are all able to levy the church tax. ${ }^{57}$ The tax, then, is broad in its application. The paragraphs that follow summarize church tax provisions applicable in Berlin, Bavaria, and Saxony, whose statutes are generally representative of those enacted by other states.

Under Germany's constitution and the statutes of the states, a religious organization that seeks and receives public law corporation status may draft its own tax ordinances. ${ }^{58}$ These ordinances, which specify the details of an organization's tax, must be approved by the state and are applicable to the organization's members. ${ }^{59}$ State statutes generally provide various forms of taxation from which religious organizations may choose. ${ }^{60}$ They include an income tax, wealth tax, tax on real property, and the imposition of special church dues called the Kirchgeld. ${ }^{61}$ The Kirchgeld is a congregationspecific tax that is not dependent upon income but is instead usually levied as a flat fee. ${ }^{62}$ In contrast, the income tax is levied as $8 \%$ or $9 \%$ of the church member's federal income tax liability. ${ }^{63}$ This results in an effective rate of roughly $3-4 \%$ of the member's income. ${ }^{64}$ An organization may decide to impose only one kind of

56. RELIGIOUS FREEDOM REPORT, supra note 36.

57. Barker, supra note 15 , pt. III.

58. Kirchensteuergesetz des Bundeslandes Berlin [KiStG] [Berlin Church Tax Act], Apr. 2, 2009, GVB1. Berlin at 23, $§ 1(1)$; Kirchensteuergesetz des Bundeslandes Sachsen [SächsKiStG] [Saxony Church Tax Act], Mar. 14, 2002, SächsGVB1. at 82, (last amended by Gesetz, Apr. 3, 2009, SăchsGVBl. at 153, $§ 1$; Kirchensteurgesetz des Bundeslandes Bayern [Bay KirStG] [Church Tax Act of the Federal State of Bavaria], Dec. 22, 2008, Bay. GVB1. at $973, \S 1$.

59. KiStG $\S \S 1(1), 12(1) ;$ SächsKiStG $\S 1(1)$.

60. See, e.g., KiStG § 3(1); SächsKiStG § 4(1); Bay KirStG $§ 4$.

61. Bay KirStG $\S 4$.

62. See also Barker, supra note $15, \mathrm{pt}$. V.

63. Id. This rate is determined by a conference of the taxing organizations. See, e.g., SarchsKiStG $\S 10(2)$. If the organizations cannot agree to a rate, the state finance administration must determine a rate. Id; see also Robbers, supra note 10, at 69.

64. In general, the top marginal rate in Germany hovers between $45 \%$ and $50 \%$, with most people in the $40 \%$ range. See KPMG, GERMAN TAX CARD (2010), available at http:/www.kpmg.de/ docs/German_Tax_Card_2010_engl.pdf. If one assumes an individual income tax rate of approximately $40 \%$ and a church tax rate of $8 \%$ of income tax, the effective rate is approximately $3.2 \%$ of income. 
tax, but the Berlin and Saxony statutes specify that a religious organization may impose them concurrently. ${ }^{65}$ If an organization selects more than one mechanism of taxation, it may credit a member's payment under one chosen regime against her liability under the other chosen regime. ${ }^{66}$ Liability is calculated on a calendar-year basis, ${ }^{67}$ and it is apportioned between spouses who file their federal income tax returns jointly but who are of different faiths. ${ }^{68}$ In addition, church taxes paid are fully deductible against income for purposes of calculating the federal income tax. ${ }^{69}$ Notably, the tax is avoidable in its entirety. Because state statutes only grant to organizations taxing authority over their members, Germans who wish to avoid the tax can do so by simply disclaiming membership in the taxing organization. ${ }^{70}$

State statutes charge religious organizations with administration and collection of the tax; ${ }^{71}$ however, religious organizations can, and generally do, enlist the state in their collection efforts. ${ }^{72}$ This is particularly true for the Catholic and Evangelical churches, which commonly make use of the government's wage withholding

65. KiStG § 3(3); SächsKiStG § 4(1).

66. KiStG § 3(3); SächsKiStG § 4(4).

67. KiStG § 3(4). But see SächsKiStG § 2(4). The Saxon statute specifies that churches are not bound to the calendar year; however, this less restrictive rule applies only if the church tax base is something other than the income tax, which is almost never the case. If income tax is chosen as the church tax base, as it is by the two major churches in Saxony (Catholic and Evangelical), the calendar year must be used to calculate the liability. $I d$.

68. KiStG § 4; SächsKiStG §§ 7-8.

69. See Einkommensteuergesetz [EStG] [Income Tax Act], Oct. 16, 1934, RGBl. at 1005, repromulgated Oct. 8, 2009, BGBl. I at 3366, 3862, last amended by Gesetz, Apr. 8, 2010, BGBl. at $386, \S 10(1)(4)$. Furthermore, contributions to churches made in excess of church tax liability are deductible under EStG $\S 10(\mathrm{~b})(1)$ so long as the deduction does not exceed $20 \%$ of the donor's income.

70. See, e.g., SächsKiStG $\S 2$ (church tax obligors are all natural persons who are members of the taxing church); SächsKiStG $\S 3$ (to withdraw from church membership, taxpayers must follow either the individual procedure of the taxing church or file an official affidavit with a local government office).

71. See KiStG $\S 1(2)$ (administration of the tax is the obligation of the tax-entitled religious community unless otherwise provided by law). Enforcement of the taxes under the statute will be selfadministered by the tax-entitled religious community according to the VerwaltungsVollstreckungsgesetz [VwVG] [Administration and Enforcement Act] of Apr. 27, 1953, BGBl. I at 157, last amended by Gesetz, July 29, 2009, BGB1. I at 2258. KiStG § 11; see also Bay KirStG § 17(1) (levies must be administered by the religious organization, which may request the State Ministry of Finance to assume the collection function).

72. Robbers, supra note 10 , at 69 . 
mechanism. ${ }^{73}$ Members of those churches, who represent roughly $70 \%$ of Germany's population, have church taxes withheld directly from their wages. ${ }^{74}$ The withheld amounts are remitted by members' employers to the state, which remits them to the governing bodies of the members' churches. ${ }^{75}$ The state's tax administration and collection laws apply with exceptions for interest, fees, and criminal penalties. $^{76}$ Finally, the churches themselves, as the taxing authorities, are competent to delay collection or entirely forgive a member's liability. ${ }^{77}$

Once a state has collected the church tax, it deducts a modest service fee and then redistributes the proceeds to the taxpayer's religious organization of choice. ${ }^{78}$ Rather than redistribute the funds to the taxpayer's particular congregation, the state instead directs them to the appropriate umbrella group. ${ }^{79}$ These include Germany's twenty Catholic dioceses and its twenty-four Evangelical Landeskirchen in addition to a number of smaller groups. ${ }^{80}$ The umbrella organizations then pay their employees and redistribute the remaining funds to the individual congregations on the basis of need. ${ }^{81}$ This system has been criticized for its lack of transparency, but it enables the umbrella organizations to account for disparate levels of wealth within their constituent congregations. ${ }^{82}$ Thus, although a German taxpayer can be certain that her funds will remain within her religion and her region, she is not assured that they will reach her own congregation.

73. Barker, supra note 15 , pt. V.

74. Id.

75. See, e.g., SächsKiStG $\S \S 9-10$. The state retains an administrative fee of 4-5\% of the amount collected. See Robbers, Minority Churches, supra note 40, at 164. This administrative fee often discourages smaller churches from taking advantage of the state collection mechanism. Id.

76. KiStG $\S 7$; Bay KirStG $\S 18(a)$; Kirchensteuergesetz des Bundeslandes Nordrhein-Westfalen [NWKiStG] [North Rhine-Westphalia Church Tax Act], Apr. 22, 1976, GV. NW. 1975 at 438, last amended by Gesetz, Nov. 18, 2008, GVB1. at 720, $\S 8(1)-(2)$.

77. KiStG $\S 9(3)$; Bay KirStG $\S 18(2)$; NWKiStG $\S 8(4)$.

78. See Robbers, Minority Churches, supra note 40, at 164; see also Barker, supra note 15, pt. V.

79. See Barker, supra note 15 , pt. V.

80. Id.

81. Id.

82. Id. 


\section{Criticisms of the Church Tax}

Although the church tax in various forms has been a part of German law since the mid 1800 s, its future has increasingly come into question. ${ }^{83}$ Some critics of the tax have suggested that the use of legal coercion in connection with religious giving is inappropriate. ${ }^{84}$ Others have noted that the tax has grown obsolete in light of Germany's increasingly secular nature. ${ }^{85}$ It may also be argued that the tax is unduly burdensome on those who pay it, because many who do not pay federal income taxes, such as retirees and the unemployed, are effectively exempt. ${ }^{86}$ In addition, the tax raises serious political questions about the nature of the relationship between state and religion in Germany. ${ }^{87}$ There also is a question of excessive entanglement: some believe that the state's involvement in the church tax renders the large religious organizations dependent upon, and therefore inextricably bound to, the will of the state. ${ }^{88}$ As a result, some believe that the tax may compromise the political neutrality of religious organizations, causing them to remain silent on issues about which they would be naturally inclined to speak or causing them to speak in support of the government when they would otherwise remain silent. ${ }^{89}$ Still others find it inappropriate that the religious organizations have a substantial role in securing social welfare at the regional level. ${ }^{90}$

Proponents of the church tax counter that the collection process is entirely bureaucratic and results in no substantive political connection between the state and religion. ${ }^{91}$ In addition, it would be too costly for churches to set up a collection system of their own. ${ }^{92}$ Furthermore, proponents argue that state participation is equitable

83. FeliX HAMmer, ReChTSFRAgen DER KirChEnSTEUER 88-89 (Mohr Siebeck 2002) (unofficial translation on file with author).

84. Id.

85. Id.

86. Id at $50-53$.

87. Id.

88. Id.

89. Id.

90. Id.

91. Id.

92. Id. 
because churches shoulder the burden for a number of educational and social service programs that would otherwise be left to the government. ${ }^{93}$ It may also be argued that the tax increases religious organizations' autonomy, freeing them from the tyranny of large donors who would seek to influence church policy. ${ }^{94}$ Finally, proponents point to the financial stability provided by the tax. ${ }^{95}$ Without it, Germany's religious organizations may be unable to sustain their current activities. ${ }^{96}$

It is unclear whether the church tax in its present form can remain a viable part of German law and culture. The question is one of vital importance, since it is a significant source of funding for many of Germany's locally provided public goods. ${ }^{97}$ In light of its significance and its uncertain prospects, the tax merits reexamination. Proponents both of retention and of reform may benefit from analysis of the United States' experience with church taxes. Although the last United States church tax was abolished in 1833, many aspects of the current German debate echo the United States' colonial and early federal history.

\section{CHURCH TAXES IN THE COLONIES AND EARLY STATES}

In 1606 , a colonial charter granted to the newly settled Virginians by King James I transplanted the English religious establishment, with its concomitant financial support, to the New World. ${ }^{98}$ Likewise, the church of the Puritans received support from the colony's sponsor, the Massachusetts Bay Company, as well as the proceeds of a tax passed by the colonial legislature in its first meeting. ${ }^{99}$ Most of the remaining colonies followed similar paths. ${ }^{100}$

93. See Robbers, supra note 10 , at 63 (churches provide charitable works, the absence of which would vitiate the constitution's guarantees of a social state).

94. Barker, supra note $15, \mathrm{pt} . \mathrm{V}$.

95. Id.

96. The church tax is unquestionably the most important source of church revenue. HAMMER, supra note 83 , at 80 ; see also Robbers, supra note 10 , at 68 (the church tax may account for $80 \%$ of the church budget).

97. Barker, supra note $15, \mathrm{pt} . \mathrm{V}$.

98. Joel H. Swift, To Insure Domestic Tranquility: The Establishment Clause of the First Amendment, 16 HoFsTRA L. REV. 473, 477-78 (1988).

99. Id. at 479. It is worth noting, however, that outside support of the Puritan churches was not ubiquitous. Puritans arriving at the Plymouth Colony in 1620 , being dissenters from the Church of 
Like Germany, then, the colonies displayed a mixture of state support of religion and regional diversity of ideology. Unlike their German counterparts, however, church taxes in the early federation of states were unable to successfully take root. Anti-establishment rhetoric surrounding the death of the church tax in the late eighteenth and early nineteenth centuries drew heavily upon the Enlightenment thinkers' emphasis on individual rights, as well as John Locke's concept of separate temporal and spiritual jurisdictions.

In 1776, as colonies began adopting their own constitutions and bills of rights, a substantial number chose to recognize religious freedom in response to widespread aversion to the establishment, but abolition of the church taxes proved controversial. ${ }^{101}$ Maryland was typical. It granted complete religious liberty to its Christian citizens but nonetheless maintained a general tax "for the support of the Christian religion." "102 Disestablishment took place state by state, beginning with Delaware and New Jersey in 1776 and ending in 1833 with the Congregational Church in Massachusetts. ${ }^{103}$ The following paragraphs provide specific examples of Maryland's church taxes as a representative example of the substance and arc of church taxes generally. They also describe two of the most heavilyargued church tax repeals: those in Virginia and Massachusetts. The Virginia and Massachusetts debates provide valuable historical insight into why the taxes failed to survive. The subject is far from obsolete. A number of the arguments raised in the Massachusetts and Virginia debates are echoed in Germany today.

\section{A. Church Taxes in the Colonies: Examples from Maryland}

As demonstrated in the paragraphs that follow, each colony handled its affairs differently, and church taxes were generally

\footnotetext{
England, did not provide for government support of their church. Id. at 478.

100. Id. passim.

101. Id. at $491-92$.

102. Arlin M. Adams \& Charles J. Emmerich, A Heritage of Religious Liberty, 137 U. PA. L. REV. $1559,1570-71$ (1989).

103. Carl H. Esbeck, Dissent and Disestablishment: The Church-State Settlement in the Early American Republic, 2004 BYU L. REV. 1385, 1457-58 (2004).
} 
levied in two forms: the general poll, or head tax, necessary to support an established church, and special levies passed to support specific local projects. By the middle of the eighteenth century, Maryland had both. ${ }^{104}$ Although it was originally a haven for Catholicism, ${ }^{105}$ Maryland later established the Church of England, and the state's laws provided for a church tax in lieu of tithes. ${ }^{106}$ One such tax was "yearly levy'd upon every Taxable person in every Parish" in the amount of forty pounds of tobacco, and its purpose was "[f]or the Encouragement of able Ministers to come and reside in this Province ...."107

Other laws were narrower and addressed specific projects. For instance, in 1765, the General Assembly authorized the levy in response to the "humble Petition" of the "Rector, Vestrymen Church Wardens and other the principal Inhabitants of Saint Andrews Parish ...."108 The petition "set forth, that the Church of the said Parish is an Antient Building, very much gone to Ruin, so that it Cannot be Expected to Stand long nor is it practicable to repair the same ...." ${ }^{109}$ In response, the authorization required the justices of the Saint Mary's County Court to assess a tax against the parish's "Taxable Inhabitants" of 200,000 pounds of tobacco, to be collected

104. For an example of a general tax, see Abridgment of the Laws of Religion, $193 \mathrm{ARCH}$. MD. 62 (1704), available at http://www.msa.md.gov/megafile/msa/speccol/sc2900/sc2908/000001/000193/ pdf/am193--62.pdf. For an example of a project-specific tax, see An Act to enable the Justices of Saint Marys County Court to Assess and Levy on the Taxable Inhabitants of Saint Andrews Parish a quantity of Tobacco for Building a Church and for other Purposes therein mentioned, 59 ARCH. MD. 264 (1765), available at http://aomol.net/000001/000059/pdf/am59--264.pdf.

105. See Patricia Bonomi, Under THE COPE OF HeAven: Religion, Society, AND Politics IN COLONIAL AMERICA 21 (2003). Lord Baltimore and the other proprietors, while Catholic, did not mention Catholicism in the charter for fear of stirring up anti-Catholic sentiment. $I d$. Nonetheless, there was a Protestant revolt in 1645 . Id. at 22 . In an attempt to keep the peace and preserve some measure of freedom for all of the colony's inhabitants, the assembly passed the "Act Concerning Religion," which was later known as the "Act of Toleration," in 1649. Id. Nonetheless, the colony later established the Church of England in 1688, when William of Orange appointed a royal governor over Maryland. See Esbeck, supra note 103, at 1487.

106. See Esbeck, supra note 103, at 1487 n.350.

107. Abridgment of the Laws of Religion, 193 ARCH. MD. 62 (1704), available at http://www. msa.md.gov/megafile/msa/speccol/sc2900/sc2908/000001/000193/pdf/am193--62.pdf.

108. An Act to enable the Justices of Saint Marys County Court to Assess and Levy on the Taxable Inhabitants of Saint Andrews Parish a quantity of Tobacco for Building a Church and for other Purposes therein mentioned, 59 ARCH. MD. 264 (1765), available at http://aomol.net/000001/ 000059/pdf/am59--264.pdf.

109. Id. 
by the sheriff in three annual installments. ${ }^{110}$ The proceeds were to be "applyed to the finishing and compleating a Parish Church for the Use of the said Parishioners and to no other use or purpose whatsoever." $" 111$

Not all special assessments related to building needs. An undated petition from St. Paul's Parish in Baltimore County prayed for a tax of three pounds of tobacco per taxable inhabitant because the church had "a very good Organ" and wished to hire "an Organist to Play the same." "In 1758, the taxable inhabitants of Charles County were subjected to a tax of two pounds of tobacco annually for payment of the organist at the Port Tobacco Church. ${ }^{113}$ In contrast, when St. Anne's Parish requested a tax of eight pounds of tobacco to pay a foreign organist, the petition was promptly rejected. ${ }^{114}$

This system of taxation remained largely unchanged until Maryland adopted its first constitution in $1776 .{ }^{115}$ The constitution, which eliminated the single church establishment, authorized the legislature to enact taxes for the support of churches generally. ${ }^{116}$ Because the state no longer had a single established church, taxes collected pursuant to the authorization were to be distributed to the church of each taxpayer's membership. ${ }^{117}$ This arrangement, often referred to as "multiple establishment" or "general establishment," was not uncommon at the time, and a number of other states adopted similar provisions. ${ }^{118}$ In addition, the constitution provided that the Church of England would retain the land that it owned and that church tax laws enacted by the legislature would remain in effect

110. Id. at 265 , available at http://aomol.net/megafile/msa/speccol/sc2900/sc2908/000001/ 000059/pdf/am59--265.pdf.

111. Id.

112. Petition from Sundry Inhabitants of St. Paul's Parish, Baltimore County, for Legislative Authority to Hire an Organist, Circa 1760-1761, 61 ARCH. MD. 499, available at http://www.msa.md. gov/megafile/msa/speccol/sc2900/sc2908/000001/000061/pdf/am61--499.pdf.

113. Proceedings and Acts of the General Assembly, 1758-1761, Introduction, $56 \mathrm{ARCH}$. MD. at xxiii, available at http://www.msa.md.gov/megafile/msa/speccol/sc2900/sc2908/000001/000056/pdf/ am56p--23.pdf.

114. Proceedings and Acts of the General Assembly, 1762-1763, Introduction, 58 ARCH. MD. at xxv, li, available at $\mathrm{http} / /$ aomol.net/megafile/msa/speccol/sc2900/sc2908/000001/000058/pdf/am58p-25.pdf and http://aomol.net/megafile/msa/speccol/sc2900/sc2908/000001/000058/pdf/am58--S1.pdf.

115. See Esbeck, supra note 103, at 1489.

116. Id.

117. Id.

118. Id. passim. 
until their expiry or repeal, despite the constitution's passage. ${ }^{119}$ Nonetheless, Anglican efforts to capitalize on the constitution's authorization for additional levies proved unpopular, and religious assessments were almost entirely phased out by $1785{ }^{120}$ Finally, in 1810, Maryland amended its constitution and revoked the legislature's power to levy religious assessments. ${ }^{121}$

When considered in retrospect, Maryland's colonial church tax statutes are remarkably quaint, but these and similar establishments were controversial throughout the colonies. The following sections discuss memorable and informative debates that erupted in Virginia and Maryland in response to very similar general establishment and church tax provisions.

\section{B. Why Were Church Taxes Repealed?: The Case of Virginia}

Like a number of other southern states, Virginia initially had a rigid establishment of the Church of England. ${ }^{22}$ The law provided for land grants to the church, compulsory attendance, punishment of blasphemy, and religious oath tests. ${ }^{123}$ Naturally, dissent was not tolerated. ${ }^{124}$ Rather, "all nonconformists vpon notice of them shall be compelled to depart the collony with all conveniencie." 125 The assembly, which was not averse to the seizure of property for religious ends, freely imposed penalties for noncompliance. For instance, the law provided that "whosover shall absent himselfe from divine service any Sunday without an allowable excuse shall forfeite a pound of tobacco...."126 Parishioners who were absent for an entire month paid a heftier sum: fifty pounds of tobacco. ${ }^{127}$

119. Id. at 1490 .

120. Id.

121. Id. at 1491 .

122. The relevant act provided that "there be an uniformity in our church as neere as may be to the canons in England; both in substance and circumstance, and that all persons yeild readie obedience unto them under paine of censure." William Waller HENING, HENING's STATUTES at LARGe I, 1619-1660 123 (R.\& W.\& G. Borton 1823).

123. Adams \& Emmerich, supra note 102, at 1563.

124. Id.

125. HENING, supra note 122 , at 277.

126. Id. at 123 .

127. Id. 
It comes as no surprise that, in this climate, Virginia taxed its citizens on behalf of the established church. Church taxes in Virginia were similar to those in Maryland. Both as a colony and as an early state, Virginia levied a religious tax. ${ }^{128}$ In form, it was a head tax levied on "tithables." 129 Although the tax was paid by the heads of estates, tithables included anyone capable of generating income: all male persons and all slave or Indian women above the age of sixteen. ${ }^{130}$ Proceeds of the tax were used for expenses of the colonial and county governments, as well as for expenses of the parish. ${ }^{131}$ The amount of the tax to be collected on behalf of the parish was calculated by adding together the parish expenses and dividing them by the number of tithables, regardless of their religious denomination or participation. ${ }^{132}$ A man's tax liability, then, was the result of this calculation multiplied by the number of tithables for which he was responsible, including himself. ${ }^{133}$

In 1624, when Virginia became a royal colony, the tithe was payable out of men's agricultural bounty. The statute provided "[t]hat no man dispose of any of his tobacco before the minister be satisfied, upon pain of forfeiture double his part of the minister's means," which were collected "out of the first and best tobacco and corn." 134 In 1629, the assembly added, "It is thought fitt that all those that worke in the ground of what qualitie or condition soever, shall pay tithes to the ministers." 135 The sum of the tax was not insubstantial. In 1727, ministers' salaries were 16,000 pounds of tobacco per year. ${ }^{136}$ In addition, each parish was required to set aside 200 acres for the construction of a parsonage, and the

128. John P. Alcock, What Genealogists Should Know about 18th Century Virginia Law, Presentation to Friends of the Virginia State Archives, Nov. 17, 1999, available at http://www. kykinfolk.com/marshall/ woliver/Virginia_Law.html.

129. Id.

130. $I d$.

131. Id.

132. Id.

133. Id.

134. HENING, supra note 122 , at 124.

135. Id. at 144 .

136. William Waller Hening, Hening's Statutes at LaRge 4, 1711-1736 204 (1820) (reprinted, University Press of Virginia 1969). 
vestrymen of the parish were authorized to levy an additional tax for construction of the buildings. 137

The situation was unsustainable. As religious diversity increased under the influence of the Great Awakening, discontent with the general establishment, and in particular its church taxes, grew. ${ }^{138}$ Scholars have estimated that by the 1750 s, at least one of every five Virginians was a dissenter. ${ }^{139}$ In fact, Thomas Jefferson thought the number to be closer to two of every three. ${ }^{140}$ Naturally, then, religious liberty was an important topic of debate when Virginia adopted its first Bill of Rights. ${ }^{141}$

At the time of Virginia's convention, anti-establishment, antichurch tax sentiment was widespread. ${ }^{142}$ Petitioners from all parts of the state made appeals for religious freedom and abolition of the church tax. ${ }^{143}$ For instance, a representative petition, received from citizens of Prince Edward County, urged that "every tax upon conscience and private judgment [be] abolished."144 The statesmen received similar pleas from Albemarle, Amherst, Buckingham, Richmond, Culpepper, and Augusta counties, among others. ${ }^{145}$ Yet even in the face of such widespread opposition, a number of the delegates believed that free exercise and the general establishment could co-exist. ${ }^{146}$ As a result, section 16 of the Declaration of Rights guaranteed free exercise to Virginians but failed to prohibit a general church tax. ${ }^{147}$ The delegates nonetheless realized that a tax

137. Id. at 206-07. Vestrymen were a group of members who managed the temporal affairs of the church, serving a function equivalent to today's modern church council. See WEBSTER's NEW WORLD DICTIONARY (3d College ed. 1988).

138. See Esbeck, supra note 103, at 1416 (the Great Awakening increased religious diversity in Virginia between the 1720 s and the 1750 s).

139. See Frank Lambert, The Founding Fathers and the Place of Religion in AMERica 226 (Princeton University Press 2003).

140. $I d$.

141. See Marc Arkin, "The Intractable Principle:" David Hume, James Madison, Religion, and the Tenth Federalist, 39 AM. J. LEGAL HIST. 148, 170 (1995).

142. See Irving Brant, Madison: On the Separation of Church and State, 8 WM. \& MARY Q. 3, 6 (1951).

143. Id.

144. Id.

145. Id.

146. See Arkin, supra note 141 , at 170.

147. See VIRGINIA DECLARATION OF RIGHTS $\$ 16$ (1776), available at http://www.nationalcenter. org/VirginiaDeclaration.html; Adams \& Emmerich, supra note 102, at 1569. Section 16 of the Declaration, which was drafted by George Mason, provided the following: 
in support of the Anglican establishment was no longer politically viable, even if an exception were made for dissenters. ${ }^{148}$ Accordingly, Virginia suspended the tax in 1776 pending further discussion, and it was fully repealed in $1779 .{ }^{149}$

Suspension of the church tax did not suspend the debate. In fact, the real story of its repeal was just beginning. The period following Virginia's adoption of the Declaration of Rights brought forth some of the most famous rhetoric on religious freedom in United States history. Although modern jurists and scholars learn of the epic struggle between Madison, Jefferson, and Patrick Henry in the context of the First Amendment, it was, in important ways, a debate about the church tax. ${ }^{150}$

Both Virginia's evangelists and her Enlightenment thinkers remained leery of the Declaration of Rights. ${ }^{151}$ Although the two groups made unlikely bedfellows, they strove in tandem toward the common goal of religious liberty. ${ }^{152}$ Both remained concerned that the legislature would enact a general church tax that would force taxpayers to participate in government sponsorship of religion. Furthermore, both worried that religious observances, including giving, were devoid of meaning as products of force. In response to these concerns, Thomas Jefferson drafted the Virginia Act for Establishing Religious Freedom in $1777 .{ }^{153}$ The Act declared that "to compel a man to furnish contributions of money for the

That religion, or the duty which we owe to our Creator, and the manner of discharging it, can be directed only by reason and conviction, not by force or violence; and therefore all men are equally entitled to the free exercise of religion, according to the dictates of conscience; and that it is the mutual duty of all to practise Christian forbearance, love, and charity toward each other.

148. See Arkin, supra note 141, at 170; Adams \& Emmerich, supra note 102, at 1573

149. Adams \& Emmerich, supra note 102, at 1573.

150. As such, it may shed light on the viability of Germany's current system.

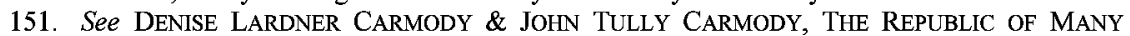
MANSiOns: Foundations of AMERICAN REligious THOUGHT 90 (Paragon House 1990); LAMBERT, supra note 139, at 221-22; John Witte, Jr., The Theology and Politics of the First Amendment Religion Clauses: A Bicentennial Essay, 40 EMORY L.J. 489, 492-94 (1991).

152. Witte, supra note 151 , at 492-94.

153. See CARMODY \& CARMODY, supra note 151, at 96-97; Daniel L. Dreisbach, A New Perspective on Jefferson's Views on Church-State Relations: The Virginia Statute for Establishing Religious Freedom in Its Legislative Context, 35 AM. J. LEGAL HIST. 172 (1991). The statute is available in WILliam WALLER HENING, HENING'S STATUTES AT LARGE 12, at 84-86 (1823) (reprinted, University Press of Virginia 1969). 
propagation of opinions which he disbelieves, is sinful and tyrannical ...."154 Jefferson then added, "even the forcing him to support this or that teacher of his own religious persuasion, is depriving him of the comfortable liberty of giving his contributions to the particular pastor, whose morals he would make his pattern ..." Accordingly, the Act provided that no man would be "compelled to frequent or support any religious worship, place, or ministry whatsoever...."156 Furthermore, no man would be "enforced, restrained, molested, or burthened in his body or goods ...."157 The law was ahead of its time, though, and found no support in the 1777 legislature. ${ }^{158}$

The Virginia debate resurfaced at the conclusion of the Revolutionary War. In 1784, Patrick Henry supported the "Bill Establishing a Provision for the Teachers of the Christian Religion," which, if passed, would have levied a general church tax on Virginia's citizens. ${ }^{159}$ The bill's tax assessment was a general one, allowing taxpayers to designate the church to which the collected funds would be distributed. ${ }^{160}$ County sheriffs would collect the levy, and after setting aside $5 \%$ as compensation, they would deliver it to the church designated by each taxpayer. ${ }^{161}$ The bill was not without support. Both John Marshall and George Washington favored it. ${ }^{162}$ In a letter to George Mason, Washington wrote, "I must confess, that I am not amongst the number of those who are so

154. HENING, supra note 153 , at 85 .

155. Id.

156. Id. at 86 .

157. Id

158. See CARMODY \& CARMODY, supra note 151, at 96-97; Dreisbach, supra note 153, at 173.

159. See Patrick Henry, A Bill Establishing a Provision for Teachers of the Christian Religion, reprinted in THE PAPERS OF GEORGE WASHINGTON DIGITAL EDITION V.2009.03 (Theodore J. Crackel ed., University of Virginia Press 2007), available at http:/candst.tripod.com/assessb.htm. For discussions of the bill, see JOHN T. NOONAN, JR., THE LUSTRE OF OUR COUNTRY 71-72 (University of California Press 1998); Dreisbach, supra note 153, at 173; Adams \& Emmerich, supra note 102, at 1573; Brant, supra note 142, at 7.

160. HENRY, supra note 159. The bill provided that "for every sum so paid, the Sheriff or Collector shall give a receipt, expressing therein to what society of Christians the person from whom he may receive the same shall direct the money to be paid . . ." Id.

161. Id.

162. See Dreisbach, supra note 153 , at 173. 
much alarmed at the thoughts of making people pay towards the support of that which they profess ...."163

As Washington's sentiment suggests, the bill itself was not extraordinary. Similar assessments were imposed by other states, including Massachusetts, Connecticut, New Hampshire, Maryland, and Georgia. ${ }^{164}$ Maryland's constitution, for instance, explicitly permitted such an arrangement. ${ }^{165}$ It provided that the legislature could, in its discretion, levy a church tax so long as each individual possessed "the power of appointing the payment over of the money collected from him, to the support of any particular place of worship or minister, or for the benefit of the poor of his own denomination, or the poor in general of any particular county ...."166 Likewise, the Massachusetts constitution provided that the legislature had the power to require towns, parishes, or religious societies "to make suitable provision, at their own expence, for the institution of the public worship of GOD, and for the support and maintenance of public protestant teachers of piety, religion and morality, in all cases where such provision shall not be made voluntarily." 167 The constitution required that the proceeds of any such levy would be "uniformly applied" to the taxpayer's own religious sect if he so chose. ${ }^{168}$ These provisions, which mirror those of Patrick Henry's bill, demonstrate that although general church taxes were not ubiquitous, they were both common and accepted in the early states.

But Henry's bill, however unexceptional, provoked an exceptional response. James Madison's Memorial and Remonstrance Against Religious Assessments directly attacked Henry's proposal. ${ }^{169}$ In it, Madison wrote: "Who does not see . . .

163. See THE Founders ON GOD AND GOVERNMENT 3 (Daniel L. Dreisbach et al ed., 2004)

164. JAMES H. HUTSON, RELIGION AND THE FOUNDING OF THE AMERICAN REPUBLIC 66 (1998).

165. See MD. CONST. Declaration of Rights art. XXXIII (1776), amended by MD. CONST. Declaration of Rights art. XXXVI (1867) and Chap. 558, Acts of 1970.

166. Id. Other states' constitutions authorized a general church levy but were less explicit. For instance, Georgia's governing document specified that no man "shall . . . ever be obliged to pay tithes, taxes, or any other rate, for the building or repairing any place of worship, or for the maintenance of any minister or ministry, contrary to what he believes to be right, or hath voluntarily engaged to do." GA. CONST. art. IV, $\$ 10(1798)$.

167. MASS. CONST. 1st pt., art. III (1781).

168. Id.

169. Adams \& Emmerich, supra note 153, at 1574; Dreisbach, supra note 153 , at 173 . In the Memorial, Madison wrote that religion is a duty that people owe to their creator, "and the manner of 
that the same authority which can force a citizen to contribute three pence only of his property for the support of any one establishment, may force him to conform to any other establishment in all cases whatsoever?" 170 The Memorial garnered tremendous support. ${ }^{171}$ One thousand five hundred fifty-two people signed the document itself, and an avalanche of ninety additional petitions with nearly 11,000 signatories followed. ${ }^{172}$ As a result, Henry's bill never made it to the floor of the assembly. ${ }^{173}$ Instead, the legislature took an opposite course and finally adopted Jefferson's Virginia Act for Establishing Religious Freedom in $1786 .{ }^{174}$ Passage of the Act marked the definitive end of the church tax in Virginia, ${ }^{175}$ although the establishment debate that it generated remains with us even today.

\section{Why Were Church Taxes Repealed?: The Case of Massachusetts}

Massachusetts's path to establishment, while also rooted in England, was vastly different from that of Virginia. Unlike the Virginians, who traveled to the New World with profit in mind, the pilgrims hoped to build a Christian commonwealth governed by biblical teachings. ${ }^{176}$ They adopted a Congregational form of government from their earliest days. ${ }^{177}$ The ecclesiastical and civil boundaries of their towns were one and the same: the concept of a

discharging it, can be directed only by reason and conviction, not by force or violence." James Madison, Memorial and Remonstrance Against Religious Assessments (1785), available at http://religiousfreedom.lib.virginia.edu/sacred/madison_m\&r_1785.html. In this, Madison drew upon the sentiment of John Locke: "The care of souls cannot belong to the civil magistrate, because his power consists only in outward force; but true and saving religion consists in the inward persuasion of the mind...." John Locke, A Letter Concerning Toleration (1689), available at http://www. constitution.org/jl/tolerati.htm; see also Andrew Koppelman, Conscience, Volitional Necessity, and Religious Exemptions, 15 LEGAL THEORY 215, 228-29 (2009). Thus, Madison argued, the right to free exercise is inalienable both because one's religion "cannot follow the dictates of other men," and because the duty to render acceptable homage to the Creator "is precedent, both in order of time and in degree of obligation, to the claims of Civil Society." Madison, Memorial and Remonstrance. Accordingly, religion is "wholly exempt from its cognizance." Id.

170. Madison, supra note 169.

171. See Brant, supra note 142, at 11.

172. See Arkin, supra note 141, at 172.

173. See Dreisbach, supra note 153, at 174 .

174. Id. For a description of Jefferson's Act, see supra notes 151-56.

175. Adams \& Emmerich, supra note 102, at 1574.

176. See Michael W. McConnell, The Origins and Historical Understanding of Free Exercise of Religion, 103 HARV. L. REV. 1409, 1422 (1990); Adams \& Emmerich, supra note 102, at 1563.

177. See McConnell, supra note 176 , at 1422. 
separate secular government did not exist for the Massachusetts settlers. ${ }^{178}$ Political franchise, of course, was limited to church members. ${ }^{179}$ As a result, the hand of the church was strong: congregations such as John Cotton's were warned to mind the boundaries of civil leadership. ${ }^{180}$ In matters of religion and morality, the church was superior, and in these areas, the civil government dared not tread without the approval and participation of the church. $^{181}$

Naturally, the Massachusetts churches were supported by taxation. ${ }^{182}$ The church tax, which was levied locally, was officially recognized as early as the $1630 \mathrm{~s} .{ }^{183}$ In 1652 , the law provided that taxes to support "convenient habitation for the use of the ministry in every town ..." would be levied "in a particular sum upon each person assessed by just rate . . . ."184 This amount was collected in the same manner as "other cases of town rates," the tax was enforced by the town constable. ${ }^{186}$

The settlers' choice of Congregational government proved unlucky for dissenters. Those who did not conform were actively persecuted. ${ }^{187}$ The Congregationalists believed, as John Ward wrote, that "[p]olipiety [a variety of sects] is the greatest impiety in the

178. Id: John Witte, Jr., One Public Religion, Many Private Religions, THE FoundERS, supra note 163, at 30. As Professor Robin Einhorn has observed, towns often began with a religious compact among the founders whose first actions were to hire a minister and build a meeting house. Robin Leigh Einhorn, AMERICAN TAXATION, AMERICAN SLAVERY 61-62 (University of Chicago Press 2006). The boundaries between the town and the church were essentially indistinguishable and seemingly avoidable only by moving beyond the established borders of any town. Id.

179. Adams \& Emmerich, supra note 102, at 1563.

180. John Cotton, An Exposition Upon the Thirteenth Chapter of the Revelation, 71-73 (London, 1655), reproduced in James F. Cooper, Jr., Higher Law, Free Consent, Limited Authority: Church Government and Political Culture in Seventeenth-Century Massachusetts, 69 NEW ENGLAND Q. 201 (1996).

181. Id.

182. See McConnell, supra note 176, at 1422; Adams \& Emmerich, supra note 102, at 1563.

183. See Kelly Olds, Privatizing the Church: Disestablishment in Connecticut and Massachusetts, 102 J. POL. ECON. 277, 278 (1994).

184. Records OF THE Governor and COMPany of the Massachusetts Bay in New ENGLAND, VOL. 2, 1628-1641, $\S 702$, at 217 (Nathaniel B. Shurtloff ed., Press of William White 1863).

185. Id.

186. See 3 RECORDS OF THE GOVERNOR AND COMPANY OF THE MASSACHUSETTS BAY IN NEW ENGLAND, \& 431 (1654) (appointing "the constable of the town to collect the same and distribute the said assessment upon such as refuse to pay.").

187. See McConnell, supra note 176, at 1423; Esbeck, supra note 103, at 1415; Adams \& Emmerich, supra note 102, at 1563. 
world."188 Accordingly, dissenters were expelled, sometimes violently. ${ }^{189}$ Thus, the Pilgrim colony, originally peopled by religious seekers, was an inhospitable environment for the independent-minded. Although actual violence against dissenters tapered off in the late seventeenth century, political disenfranchisement and religious intolerance remained problematic. ${ }^{190}$

Just as in Virginia, the tide began to slowly turn with the dawn of the Great Awakening. ${ }^{191}$ The popular Evangelical movement spread religious diversity throughout the colonies during the mid-seventeen hundreds, and Massachusetts was not spared. ${ }^{192}$ At the close of the Revolutionary War, the fastest growing sects in the newly-formed state were Evangelical. ${ }^{193}$ The converts believed that God had not surrendered his sovereignty to the state, and that he did not need the state's assistance in raising revenue. ${ }^{194}$ Religious uniformity became impossible, and dissenters were sometimes permitted to direct their tax dollars to ministers of their own denomination. ${ }^{195}$ Nonetheless, the Massachusetts establishment weathered the Revolutionary War with greater aplomb than most. ${ }^{196}$ Unlike the Quakers, who remained neutral, and the Anglicans, who were at least nominally

188. See McConnell, supra note 176 , at 1422.

189. Id. See Esbeck, supra note 103, at 1415; Adams \& Emmerich, supra note 102, at 1563. Baptists were explicitly banished by statute in 1644 , and in one of the more notorious instances of intolerance in colonial history, four Massachusetts Quakers were executed by hanging after returning from expulsion. See McConnell, supra note 176, at 1423. Of course, the Salem Witch Trials also come to mind.

190. McConnell, supra note 176, at 1423. For instance, Quakers were forbidden from publicly meeting until 1697. See BONOMI, supra note 105, at 29.

191. See Esbeck, supra note 103 , at 1416.

192. Id.

193. See LAMBERT, supra note 139 , at 221

194. Id. See William H. Leach, Financing the Local Church, 332 ANNALS OF AM. ACAD. POL. \& SoC. SCI. 70, 73 (1960). The evangelicals were not the only people who were worried. In his address to members of the Boston Missionary Society, Seneca chief, Red Jacket, had this to say:

Brother: you say you have not come to get our land or our money, but to enlighten our minds.

I will now tell you that I have been at your meetings, and saw you collect money from the meeting. I cannot tell what this money was intended for, but suppose that it was for your minister, and if we should conform to your way of thinking, perhaps you may want some from us.

Red Jacket, Speech to the Iroquois Six Nations (1805), http://churchstatelaw.com/historicalmaterials /8_2_4.asp.

195. See LAMBERT, supra note 139 , at 221 ; Olds, supra note 183 , at $278-79$.

196. See McConnell, supra note 176 , at 1437. 
loyal to England, the Congregationalist leaders aligned themselves with the colonies in the fight for independence. ${ }^{197}$ As a consequence, the Massachusetts establishment maintained an element of vitality that its Virginian counterpart lacked, ${ }^{198}$ which helped to postpone the inevitable church tax repeal. ${ }^{199}$

The Evangelical movement in Massachusetts eventually found its defining voice in Isaac Backus. ${ }^{200}$ A Baptist convert and outspoken preacher, Backus viewed the Congregational establishment as a government incursion of sectarian jurisdiction. ${ }^{201}$ Like Madison's Memorial and Remonstrance, Backus echoed Locke: "it is needful to observe, that God has appointed two kinds of government in the world, which are distinct in their nature, and ought never to be confounded together; one of which is called civil, the other ecclesiastical government." 202 The civil government, according to Backus, exceeded its authority when it levied taxes on behalf of the ecclesiastical government. ${ }^{203}$

Backus also recognized Massachusetts's establishment as an affront to the principles upon which the revolution was founded. ${ }^{204}$ He analogized the Baptist claim for relief from church taxes to the patriots' claims for relief from English taxes. ${ }^{205}$ Furthermore,

\footnotetext{
197. See id.

198. See id.

199. See LAMBERT, supra note 139 , at 221-25.

200. See Esbeck, supra note 103, at 1432.

201. See id. at 1435 .

202. See Isaac Backus, An Appeal to the Public for Religious Liberty Against the Oppressions of the Present Day (1773), available at http://churchstatelaw.com/historicalmaterials/8_2_7.asp.

203. Id. Even Solomon, Backus observed, was not entrusted with governance over church affairs; rather, the exact dimensions of the Temple and the courses of priests and Levites had been dictated to him by God. Id. "How came the people of the world," Backus then queried, "by any ecclesiastical power?" Id.

204. See id.

205. See Esbeck, supra note 103, at 1436; see LAMBERT, supra note 139, at 224. This position was also taken by another Baptist minister, John Allen. See LAMBERT, supra note 139 , at 224 . In an address to the Massachusetts General Court, Allen said the following:

You tell your governor that the Parliament of England have no right to tax the Americans ... . because they are not the representatives of America; and will you dare to tax the Baptists for a religion they deny? Are you gentlemen their representatives before GOD, to answer for their souls and consciences any more than the representatives of England are the representatives of America? ... . [I]f it be just in the General Court to take away my sacred and spiritual rights and liberties of conscience and my property with it, then it is surely right and just in the British Parliament to take away by power and force my civil rights and property without my consent; this reasoning, gentlemen, I think is plain.
} 
Backus attacked the premise that church taxes were necessary for the preservation of civil society. ${ }^{206} \mathrm{He}$ observed rather caustically of the Congregational leaders:

[W] hen it comes to be calmly represented, that, religion is voluntaty [sic] obedience unto God, which therefore force cannot promote; how soon do they shift the scene, and tell us, that religious liberty is fully allowed to us, only the state have in their wisdom thought fit to tax all the inhabitants, to support an order of men for the good of civil society. A little while ago it was for religion, and many have declared, that without it we should soon have no religion left among us: but now tis to maintain civility. Though by the way it is well known, that no men in the land, have done more to promote uncivil treatment of dissenters from themselves, than some of these pretended ministers of civility have done. ${ }^{207}$

The power to levy church taxes for the preservation of civility had reinforced the power of Massachusetts leaders to perpetrate incivility against their Baptist, Methodist, and Quaker neighbors. For instance, Backus noted that church taxes, left unpaid, could result in the debtor's imprisonment. ${ }^{208}$ Local ministers and other officials, even knowing the inevitable result, often refused to release the debt. ${ }^{209}$ Backus added, "we have had instances of serious christians, who must have died in prison for ministers rates, if christianity and humanity had not moved people to provide them that relief, which neither those ministers nor the law that upholds them have done. ${ }^{, 210}$

\footnotetext{
Id. In a Boston pamphlet, Backus added:

These evils cleaved so close to the first fathers of the [sic] Massachusetts, as to move them to imprison, whip and banish men, only for denying infant baptism, and refusing to join in worship that was supported by violent methods: yet they were so much blinded as to declare, That [sic] there was this vast difference between these proceedings and the coercive measures which were taken against themselves in England ....

Backus, supra note 202.

206. Backus, supra note 202.

207. Id.

208. Id.

209. Id.

210. Id.
} 
Backus's story continued in September of 1779, when delegates to Massachusetts's Constitutional Convention called upon him to assist them in drafting the state's new Bill of Rights. ${ }^{211}$ Backus's proposal would have ensured free exercise and would have revoked the state's power to levy taxes on behalf of churches, whether or not apportioned on the basis of taxpayers' membership. ${ }^{212}$ It would finally have freed Baptists and other dissenters from a duty that they believed to be illegitimate. But Backus's work was rejected, and the Convention instead opted to incorporate an article that authorized the legislature to promulgate general church taxes. ${ }^{213}$

Article III, which was adopted in lieu of Backus's provision, proved to be contentious both before and after its passage. ${ }^{214}$ The article provided that the Commonwealth could require the towns to support "the Public worship of GOD" at their own expense. ${ }^{215}$ In addition, the article allowed any dissenter to direct tax dollars to his own denomination, provided that he regularly attended worship there. ${ }^{216}$ Although the article needed a $66 \%$ rate of approval to pass, it received only $59 \%$ of the vote. ${ }^{217}$ A number of the disapproving votes, however, contained suggestions for amendment. ${ }^{218}$ The Convention decided not to count these ballots, and their exclusion led to the article's passage. ${ }^{219}$ Despite the fact that, at the time of the Convention, Massachusetts had levied a general church tax for over a century, the debate did not end with the tax's elevation to constitutional status. ${ }^{220}$ Some Baptists, upset with the ultimate

211. Adams \& Emmerich, supra note 102, at 1592.

212. Id. The article would have provided:

As God is the only worthy object of all religious worship, and nothing can be true religion but a voluntary obedience unto his revealed will, of which each rational soul has an equal right to judge for itself, every person has an unalienable right to act in all religious affairs according Id. to the full persuasion of his own mind, where others are not injured thereby.

213. Id. at $1592-93$.

214. See Esbeck, supra note 103, at 1443; see also LAMBERT, supra note 139, at 223.

215. See Witte, supra note 178 , at 31-32 (quoting MASS. CONST. of 1780 art. III).

216. Id.

217. See Esbeck, supra note 103, at 1443-44.

218. Id.

219. Id. at $1443-44$.

220. See LAMBERT, supra note 139 , at 223. 
institutionalization of a tax that trammeled their right to religious freedom, chose civil disobedience and refused to pay. ${ }^{221}$

Although the new article nominally placed all Protestant denominations on equal footing, the groups were not treated equally in practice, a situation that exacerbated Evangelical discontent. ${ }^{222}$ Town treasurers did not always respect the dissenters' rights. ${ }^{223}$ For instance, in his Appeal to the Public for Religious Liberty, Backus recorded for posterity that "William White[,] a regular member of the baptist church in Ashfield, who lives in Chesterfield, and has had his standing in said church certified according to law; yet had a cow taken from him on August 25, 1773, and sold the 30th, for the pedobaptist ministers rate . ..."224 In addition, some courts held that only incorporated organizations could receive the funds that were earmarked by dissenters. ${ }^{225}$ This rule posed a problem because churches that were too small to employ a full-time minister were regularly denied corporate registration. ${ }^{226}$ Furthermore, the rule required Evangelical dissenters to seek the state's approval, an action that directly conflicted with church doctrine. ${ }^{227}$

In the face of mounting discontent, Massachusetts gave way and statutorily voided the judicial distinction between corporate and unincorporated churches. ${ }^{228}$ The new law provided that a dissenter could direct funds to "teachers of an unincorporated as of a corporate religious society," 229 but it was too little, too late. In 1833, when a group of delegates tried to strengthen the Article III church tax through constitutional amendment, the state instead passed a disestablishment amendment by an overwhelming majority. ${ }^{230}$

221. See Esbeck, supra note 103, at 1444 n. 196.

222. See Witte, supra note 178 , at 31 .

223. Id.

224. Backus, supra note 202.

225. See Esbeck, supra note 103, at 1446-47 (citing the Cutter case); Witte, supra note 178, at 30; see also Barnes v. Inhabitants of First Parish, 6 Mass. 401 (Mass. 1810); Lovell v. Inhabitants of Parish, 7 Mass. 230 (Mass. 1810); Turner v. Inhabitants of Second Precinct, 7 Mass. 60 (Mass. 1810).

226. See Witte, supra note 178 , at 31 .

227. See Esbeck, supra note 103, at 1447; Witte, supra note 178, at 31.

228. See An Act Respecting Public Worship and Religious Freedom, 1811 Mass. Statutes, ch. 6 (1811).

229. Id. $\$ 1$.

230. See the Commonwealth of Massachusetts, A Manual for the Constitutional CONVENTION 177 (Wright \& Potter, 2d ed. 1917). The amendment was adopted by a vote of 32,234 to 3,273. See John M. SWOmLey, Religious LiberTy and the SECular State 28 (1987). 
New Article XI of the Massachusetts Constitution provided:

[T] he several religious societies of this Commonwealth, whether corporate or unincorporate ... shall ever have the right to elect their pastors or religious teachers, to contract with them for their support, to raise money for erecting and repairing houses of public worship, for the maintenance of religious instruction, and for the payment of necessary expenses .... ${ }^{231}$

The legislature's power to pass religious levies was gone. ${ }^{232}$ Church taxes had been permanently, albeit ploddingly, abolished in the United States.

\section{GeRMAN AND EARLY AMERICAN CHURCH TAXES: \\ A COMPARISON}

Although German and early American church taxes are divided by an ocean and nearly two centuries, the foregoing accounts suggest that they bear more than a passing resemblance to one another. Both reached their logical conclusion in generalized assessments with exceptions for dissenters, and both have, at most times, fallen within the auspices of the state's collection authority. ${ }^{233}$ The German system, as it currently stands, has weathered nearly two hundred years and five iterations of government. The American system also lasted nearly two hundred years, and it, too, witnessed political upheaval. ${ }^{234}$ Why, then, has the German system persisted in modernity when the American system could not?

The answer inheres in the differences between the two systems. First, the German government's consistent acknowledgement of religious sovereignty effectively addresses the anti-establishment argument raised by the American Evangelical dissenters. Second, the ability of a German citizen to opt out of the tax attenuates, although it does not completely eliminate, the Enlightenment-based

231. MASS. CONST. art. XI (1833).

232. Id.

233. See discussion supra Part II.

234. See discussion supra Part III. 
argument against encroachment upon individual religious liberty. Finally, the conception of the good underlying the German tax is more closely aligned with the German public's conception of the good than was the case for the American tax. These three differences are key to any interpretive or normative assessment of the German system, and they are discussed in greater detail in the paragraphs that follow.

\section{A. Differences in Institutional Autonomy}

Both the German and American church tax systems began with established churches that were active participants in government. ${ }^{235}$ In Germany, however, churches have consistently been treated as independent actors competent to conclude treaties and to collect tithes. Indeed, even today, German states honor existing concordats with the religious organizations, and religious organizations remain active participants in public life. ${ }^{236}$ Furthermore, Germany's constitutional court has recognized that religious organizations treated as public law corporations possess some measure of sovereignty. ${ }^{237}$ This sovereignty is not merely a notional one over the spiritual realm, as was envisioned by the American Evangelical dissenters, but a set of temporal rights granted to public law religious organizations that are treated as public law corporations. ${ }^{238}$ Within this set of rights is the autonomy to choose whether and how to interact with the government vis-à-vis the church tax. ${ }^{239}$

Unlike the American system, Germany's constitution lodges taxing power in the religious organizations themselves. ${ }^{240}$ Organizations may choose whether to apply for public law corporation status, and, if accepted, they may choose whether to levy the tax. ${ }^{241}$ If a religious organization chooses to levy the tax, it is faced with an additional decision: what sort of tax to levy. ${ }^{242}$

235. See generally discussion supra Parts III and IV.

236. See RELIGIOUS FREEDOM REPORT, supra note 36.

237. See 102 BVerfGE 379 , supra note 47 , at 388 .

238. Id. at 371.

239. See discussion supra Part II.

240. See supra note 76 and accompanying text.

241. See discussion supra Part II.

242. KiStG, supra note $58, \S 3(1)$, SăchsKiStG, supra note $58, \S 4(1)$. 
Then, depending upon the state of residence and the type of tax chosen, the religious organization may also choose the amount of the tax and who will be exempt from its reach. ${ }^{243}$ Finally, and importantly, it is the religious organization, and not the state, that decides who will collect the tax. ${ }^{244}$ State involvement in church tax collection only takes place upon the request of the levying organization. ${ }^{245}$ Thus, there is no possibility for the sort of doctrinal conflict that plagued early Virginia and Massachusetts. German organizations whose creeds mandate strict separation may choose that avenue. In effect, religious organizations may tailor their level of government interaction to meet their doctrinal requirements. This system of unilateral boundary setting by the organizations themselves is undoubtedly one strong factor in the church tax's persistence in Germany, whereas unilateral boundary setting by the government was undoubtedly a strong contributor to the tax's abolition in the United States. ${ }^{246}$ Religious organizations in the United States had no legal right to avoid the church tax system. Thus, religious sovereignty and institutional autonomy are protected by the German system in a way that was impossible under the American states' general establishments.

The concept of religious sovereignty in the early United States was more closely cabined, and the institutional autonomy of dissenting congregations was severely strained. Much of the late colonial and early federal thinking on religious sovereignty drew upon John Locke's assertion that the "care of souls cannot belong to the civil magistrate, because his power consists only in outward force; but true and saving religion consists in the inward persuasion of the mind . . ."247 It follows from this proposition that religious organizations should act on the basis of persuasion rather than force; therefore, in a Lockean state, they would lack what we conceive of

243. See KiStG $\S 1(2)$ (administration of the tax is the obligation of the church), $\S 11$ (description of enforcement of the taxes under the statute).

244. See SächsKiStG $\$ \S 9-10$.

245. See id.

246. Other influences were, of course, myriad. I certainly do not suggest that the American emphasis on individual liberty and freedom from taxation should be discounted.

247. Locke, supra note 169. 
today as temporal sovereignty. Certainly, under this ideal, they could not possess a state-enforced power to tax. ${ }^{248}$

The United States' different regard for religious organizational sovereignty was also evidenced in the structure of the early church taxes, which severely restricted institutional autonomy. In Maryland, Virginia, and Massachusetts, the taxing power was lodged in either the local legislature or the state legislative assembly. ${ }^{249}$ Religious organizations that sought additional public funds had no independent authority and were required to seek a legislative dispensation. ${ }^{250}$ This arrangement placed religious organizations in a subservient, rather than an independent, position. ${ }^{251}$

\section{B. Differences in Individual Religious Liberty}

A second significant difference between the American and German church taxes is the level of protection provided for individual religious liberty. The American system burdened all taxpayers regardless of their religious affiliation. ${ }^{252}$ In its early days, all of the tax dollars raised under the American system were directed to a single established church. ${ }^{253}$ Later, dissenters could direct their

248. The philosopher's own writing confirms this position. Referring to the respective roles of civil government and religious organizations, Locke exhorted his readers:

[T] he Church itself is a thing absolutely separate and distinct from the commonwealth. The

boundaries on both sides are fixed and immovable. He jumbles heaven and earth together, the

things most remote and opposite, who mixes these two societies, which are in their original,

end, business and in everything perfectly distinct ....

Id. In Locke's system, then, the church would only have jurisdiction over sectarian matters, and in these matters, the secular government would not intrude. These sentiments were employed to varying degrees by Madison, Jefferson, Backus, and others, and they indicate that the American conception of religious sovereignty during the disestablishment period differed greatly from that of the German constitutional court today. Church sovereignty in the early states was, at best, ephemeral; in Germany, it is actual.

249. See discussion supra Part IV.

250. Id.

251. Furthermore, under the general establishment, even those congregations opposed to religious taxes were benefited by them when parishioners directed tax dollars to them. The Evangelical dissenters believed that rendering a tithe under governmental compulsion stripped the gift of its religious significance. They also believed that God required them to operate free from government support and coercion. They needed an exemption from the tax rather than the benefit of it. This option, which exists under the modern German system, was conspicuously absent from the American one.

252. See discussion supra Part VI.

253. $I d$. 
tax dollars to their own congregations, or in some instances, to public charity. ${ }^{254}$ But dissenters could not refuse to pay, and they could not tailor the amount of their giving to their individual beliefs. ${ }^{255}$ Nor could they engage in cyclical giving to account for changes in their own lives or changes in the life of their particular congregation. $^{256}$ The religious tax, like other true taxes, was unavoidable.

The German system protects individual religious liberty more effectively. Its recognition of religious sovereignty and institutional autonomy results in a de facto recognition of individual religious liberty. This is because religious organizations, rather than the government, levy the tax. Members of these organizations fall within the taxing jurisdiction of their congregations of their own volition. Consequently, those members who object to their religious organization's imposition of the tax may avoid it by disclaiming their membership, or, to say it differently, by "opting out" of the congregation's jurisdiction. In fact, dissatisfied congregants may even take up membership in an organization of a similar denomination that does not levy the tax. Although the suggestion of changed membership resonates harshly at first, by definition, individuals who object to the giving obligations imposed by their religious organizations harbor beliefs that differ from those espoused by the organizations themselves. This difference between the personal belief of an individual and the doctrine of that individual's religious organization falls outside of the German government's purview. It is wholly within the individual's discretion to decide whether the difference is significant enough to merit attrition. Such a choice was not available to taxpayers under the American system. Accordingly, individual religious liberty is preserved, albeit imperfectly, to a greater extent in the German system. 


\section{Differences in the Conception of the Good}

A third significant difference between the German and the American systems is the conception of the good undergirding them. At the time of American disestablishment, it was argued that church taxes were necessary to pay the salaries of Christian ministers, who aided in the preservation of civil society. ${ }^{257}$ In other words, proponents of religious assessments asserted that churches should benefit from government establishment because they provided moral instruction necessary to the maintenance of social order. ${ }^{258}$ In fact, a significant portion of early American church tax dollars were paid directly to Congregational and Anglican ministers whose job it was to expound upon the evils of drinking, dancing, and carousing. ${ }^{259}$

In contrast, Germany's established religious organizations have assumed an important additional role: in many cases, they are the predominate local suppliers of public goods. Accordingly, they are responsible for the provision of a substantial portion of local social services. ${ }^{260}$ These services, which are equally available to members and non-members in most cases, include kindergartens, recreation centers, schools, nursing homes, and hospitals, among other things. ${ }^{261}$ Unlike early American churches, then, German religious organizations have adopted a separate secular governance function in response to societal change, causing Professor Franz Walter to describe them as "service points for the provision of welfare services and ritual acts when they are required in the life cycle of a secularised society that is otherwise indifferent to churches."262 This adaptation to secularization - a conception of the good that has evolved in response to societal evolution - stands in stark contrast to the inflexible position of early American religious institutions and

257. See Dreisbach, supra note 153 , at 173 ; THE FOUNDERS ON GOD \& GOVERNMENT, supra note 163 , at $3-4$.

258. Id.

259. $I d$.

260. See Robbers, supra note 40 , at 63 (churches provide charitable works, the absence of which would vitiate the constitution's guarantee of a social state).

261. RELIGIOUS FREEDOM REPORT, supra note 36; see also Christine Sticht, The Role of Churches in Germany-Introduction, GOETHE-INSTITUT, May 2004, http://www.goethe.de/ges/phi/dos/rkd/en 2012816.htm.

262. Sticht, supra note 261. 
may, in some part, explain the persistence of Germany's church tax system.

\section{The Challenge of INCREASING RELIGIOUS Diversity}

Despite the fact that Germany's church tax system preserves the autonomy of religious organizations, allows individuals to opt out of payment, and funds the provision of public goods, a number of commentators have called for both governmental and ecclesiastical reassessment of the practice. ${ }^{263}$ Although modern day Germany is politically, socially, and economically quite different from the early United States, some of the arguments advanced by German critics today are similar to those espoused by the famous voices of the American disestablishment. Both share a concern that religious taxes impinge upon individual liberty. Both find such taxes questionable in light of a change in the religious composition of the society: increased diversity in the case of the early states and increased diversity and secularism in the case of Germany. Finally, both question the influence of the state upon the church and vice versa.

The following paragraphs assess the likelihood that these shared criticisms will produce a shared result and conclude that Germany's tax need not meet the same fate as its American predecessor. Differences in the German tax's structure and the use of its proceeds make it fundamentally different from the early American system, and, as a result, vitiate the doctrinal concerns raised by the American Evangelical dissenters and Enlightenment politicians. Instead, increased secularism and religious diversity draw the continued vitality of the German system into question. An appropriate response to this metamorphosis is crucial. Failure of the German church tax system would jeopardize more than the provision of religious services; it would have a significantly negative impact on the provision of locally funded public goods.

263. See, e.g., Christa Pongratz-Lippitt, Funding System of German Church Challenged, THE TABLET, Aug. 22, 2009, available at http:/www.thetablet.co.uk/article/13541 ("A canon lawyer's attempts to end compulsory church tax in Germany have thrown the German Church on the defensive and triggered a national debate about the justification of the tax."). 


\section{A. Increased Religious Diversity as a Destabilizing Influence}

If neither the evangelical nor the Enlightenment arguments against the early American church tax find purchase in the modern German system, is the German tax necessarily on stable footing? Increased religious diversity in the early United States as a result of immigration and the Great Awakening destabilized the various states' establishments. The presence of religious minority groups in communities likely led to greater tolerance of differently-minded neighbors. And the principle of tolerance on a personal level, although perhaps slow to catch fire in more homogeneous areas of the country, dovetailed with the Revolutionary idea that all men are created equal. Increased acceptance of religious differences likely contributed to increased religious mobility from established churches to non-established ones.

Similar influences may be at work in Germany today. ${ }^{264}$ The country has seen increases in both religion and agnosticism in different segments of the population. ${ }^{265}$ First, and notably, the reunification of East and West Germany in 1990 brought a sizeable agnostic and atheist population into the religious framework established by the Weimar Constitution. ${ }^{266}$ Religious organizations were highly disfavored by East Germany's communist government, and even today, less than twenty percent of the population of the former East is affiliated with a religious organization. ${ }^{267}$ Although these citizens were originally concentrated in their states of origin, in the years since Germany's reunification they have migrated throughout the country. ${ }^{268}$ It is likely that their ideas will travel with them. In other words, redistribution will contribute to increased acceptance of religious non-membership in the heavily religious, if mostly unobservant, West. ${ }^{269}$

264. William E. Downey, Church Taxes in Germany: Not Taking the Pledge, 114 CHRISTIAN CENTURY 23 (1997) (demographic shifts and social development have corresponded with lower church tax revenues).

265. Id.

266. See Conway, supra note 31, at 727-31; RELIGIOUS FREEDOM REPORT, supra note 36.

267. RELIGIOUS FREEDOM REPORT, supra note 36.

268. Id.

269. Rainer Ilgner, former Deputy Secretary of the German Catholic Bishops' Conference, described the evolving situation succinctly: "Society has changed now, and many people think that if 
The reunification of East and West is not the only source of religious diversity currently putting pressure on the German social structure. Immigration from countries that are predominantly Muslim has increased the presence of non-Christian religious organizations in Germany. ${ }^{270}$ Although it is impossible to predict the impact of these organizations on the German establishment, it is likely that the church tax system will be forced to adjust to changing demographics. Historically, Muslim congregations have not applied for public corporation status, primarily because they are independent and not governed by an umbrella organization such as the Protestant Landeskirche or Catholic Diocese. ${ }^{271}$ Furthermore, individual congregations have been divided on the issue of government interaction. $^{272}$ When viewed in terms of the geographic concentration of Muslim communities, this non-participation may be problematic. Unlike their Catholic or Evangelical counterparts,

it's all right to leave a spouse, why can't they leave the church?" Craig R. Whitney, Church Tax Cuts the German Fold, N.Y. TIMES, Dec. 28, 1992, at A12.

270. RELIGIOUS FREEDOM REPORT, supra note 36.

271. With government facilitation, an umbrella group called the Coordination Council of Muslims in Germany was founded in 2007. See New Umbrella Group Founded, SPIEGEL ONLINE, Apr. 11, 2007, http://www.spiegel.de/international/germany/0,1518,476563,00.html. To date, however, the group has proved divisive and has not applied for public law corporation status. See Charles Hawley, Germany's Difficult Debate with Its Muslim Community, SPIEGEL ONLINE, Mar. 14, 2008, http://www.spiegel.de/international/germany/0,1518,541493,00.html (the Muslim Coordinating Council, which tends toward conservatism, represents only twenty percent of Germany's Muslims); Mark Chalîl Bodenstein, Muslim Associations: New Figures but No End to the Debate, DEUTSCHE ISLAM KONFERENZ, Feb. 10, 2009, available at http://www.deutsche-islam-konferenz.de/SubSites/ DIK/EN/InDeutschland/MuslimOrganisationen/VerbaendeMLD/verbaende-mld-node.html (although four Muslim organizations claim a stake in the governmental debate, fewer than twenty-five percent of Muslims feel that they are adequately represented by any of these groups).

272. RELIGIOUS FREEDOM REPORT, supra note 36. Recently, however, the German government and some Muslim leaders have made a concerted effort to form an umbrella organization that would apply for public law corporation status. Id; see also New Umbrella Group Founded, supra note 271 (reporting a new umbrella group, Coordination Council of Muslims in Germany, formed to represent interests of Muslims before the German government). Although formation of the group was initially hailed as a success, it seems to have made little progress. See Hawley, supra note 271; Bodenstein, supra note 271 . A variety of possible results come to mind vis-à-vis the church tax. First, a significant portion of the Muslim community could coalesce in favor of public corporation status, but in light of past disagreements, this seems unlikely. Second, the Muslim community could uniformly reject the effort. This, too, seems unlikely. Third, and most probable, the Muslim community could engage in internal debate on the desirability of participating in the church tax system. Unlike prior Muslim conversations on the issue, this one will have the full attention of the government due to its role as a catalyst, and the full attention of the public, which has struggled with integration. A focused debate on the merits and demerits of the church tax is a prerequisite to meaningful change of the system. Thus, it is possible that Muslim immigration to Germany may be a continental reprise of the role played by conversion during the Great Awakening in the United States. 
Muslim congregations that provide community services are not assured a stable source of funding. In addition, it is possible (indeed, likely) that the inclusion of Muslim congregations as public corporations and the provision of public goods to people of all faiths by those congregations would promote integration overall.

What is the likely church tax outcome of Germany's changing demographics? Increased diversity of religious beliefs in West Germany, where church tax constituents are concentrated, may lead to increased acceptance of mobility between and out of religious organizations. It may also lead to increased concern about freeriding. These changed positions will lend additional strength to public perception of religious affiliation as a matter of personal choice and will weaken the moral argument against transferring from a religious organization that levies a tax to one that does not. ${ }^{273}$ In fact, data indicate that this may already be taking place. ${ }^{274}$ In addition, discussion within and about the Muslim community will focus national attention on the treatment of religious organizations as public law corporations. ${ }^{275}$

These two factors-increased religious diversity and increased debate-were present in the American disestablishment, albeit in different forms, and may force established Germany to reevaluate its position on the connection between religion and state-enforced charitable giving. In such an instance, state governments must consider whether the public goods and services provided by religious organizations are essential, and if so, decide how best to fund them. It is plausible that governments could choose to leave non-essential services in the care of religious institutions but increase government financial support of those services. This is not,

273. Of course, one would expect fewer inter-faith transfers than intra-faith transfers. So, for instance, if all Jewish congregations levy the tax, the effect of increased secularism and religious diversity will affect them less. Protestant congregations, on the other hand, may see substantial shifts in membership, because some levy the tax and others do not.

274. Note, though, that attrition from the church tax system could also be a reaction to Germany's continued imposition of the solidarity tax, which was originally earmarked for expenses associated with the country's reunification. See Downey, supra note 264, at 23 (important factors in decline of church tax revenue include increased retirement, high unemployment, demographic shifts, and changes in the federal tax laws).

275. See Hawley, supra note 271 (ongoing debate over religious education and the wording of a document declaring Muslim allegiance to the constitution-required for public law corporation status-will spark an overdue examination of overall integration). 
however, the only alternative. Instead, governments could create coextensive non-sectarian taxing jurisdictions. Stated differently, German states could permit secular quasi-governmental actors to engage in non-geographically bounded taxation, as described in the next section.

\section{The Church TaX as a Non-GeOgRaPhically Bounded LOCAL TAX}

In essence, the German church tax is a local tax delineated not by geography, but by religious preference. The proceeds of the tax, while used in part for religious purposes, are also used to fund essential public goods that are available to individuals regardless of their religious affiliation. When viewed in combination with the limited form of sovereignty vested in religious organizations by Germany's constitution and highest court, it becomes clear that the viability of the tax need not rest with the religious conviction of Germany's citizens or with the taxing will of its local politicians. Instead, Germany may adapt its existing structure to the changing religious composition of its society.

One way to accomplish this goal would be to create nongeographically bounded tax jurisdictions that would mimic the tax jurisdictions of religious organizations. These jurisdictions would include only individuals who are not members of religious organizations that levy a tax. The term "non-geographically bounded" is appropriate because, although the jurisdiction of religious organizations depends to some extent on geography, its key denominator is the willing participation of members. By disclaiming membership in a particular taxing organization, individuals can effectively opt out of that organization's reach. The same would be true of secular non-geographically bounded jurisdictions.

The creation of such jurisdictions within German localities could serve several beneficial functions. First and foremost, in areas where the church tax is ineffective, such as Muslim communities or the former East, non-sectarian opt-out tax jurisdictions could fulfill the role typically assumed by the Catholic and Evangelical churches, providing structural equivalence between these communities and 
their heavily Christian counterparts. Structural uniformity among localities should equate to greater efficiency and equality in distribution of state social services and benefits. Second, the use of non-sectarian opt-out tax jurisdictions could alleviate current church taxpayers' concerns about free-riding. This could lead to a greater perception of fairness among current taxpayers which, in turn, could result in a lower attrition rate among the existing jurisdictions.

The existence of secular jurisdictions as counterparts to sectarian jurisdictions would also provide religious and non-religious individuals with equal access to moral opportunities, thus serving an important expressive function. Under the current system, individuals who support taxation for the provision of public goods by a nongovernmental organization must also choose membership in a religious organization. Individuals having a preference for the former position but not the latter are faced with two unsatisfactory choices: they can participate in the tax and join the organization, or they can fail to participate in the tax and avoid joining the organization. Neither of these options expresses the individual's true preference. By disaggregating participation and religious affiliation, adoption of secular non-geographically bounded tax jurisdictions would provide a full range of expressive options.

Finally, the analysis is not pertinent solely to Germany. As I will explore more fully in a subsequent work, Germany's church tax system provides insight not only into the uniquely American debate surrounding disestablishment in the United States, but also into potentially novel forms of local public finance. A system of public finance modeled after the German tax would have two salient features: first, it would be bounded by preference affiliation rather than geography, and second, participants could remove themselves from the taxing jurisdiction by ending their preference affiliation. More simply put, it would be a system of opt-out public finance that could be used to supplement or replace portions of non-essential spending in current local systems. Although a system of opt-out taxation seems wildly improbable at first blush, the high participation rate in Germany's system indicates that its basic 
structure is not without merit. ${ }^{276}$ In some United States localities, stickiness of a default option, people's unwillingness to deviate from the norm of public support, and actual enthusiasm for public goods may result in participation levels similar to those observed in Germany.

Even if most residents of United States localities opted out of participation in a preference-bounded jurisdiction, such a system could still produce democratic gains. Local governments could obtain the benefit of electoral input and collaborative decisionmaking by allowing taxpayers to opt out of their obligation to pay for appropriately identified non-essential expenses. If viable, the use of an opt-out system to engage in proportional decision-making on certain government non-essential expenditures would alter the dialogue between residents and local governments, foster debate among residents themselves, and provide a more equitable and efficient allocation of resources. To be clear, I do not forward preference-bounded revenue collection solely as a means of raising revenue; rather, it also should serve as both an instrument and gauge of democracy. The resulting creation of political dialogue on discretionary governmental spending could result in resource allocation that more accurately reflects the allocation preferences of constituents while also giving a voice to those constituents who are marginalized by traditional representative government. The result could be something not yet achieved by local tax systems in the United States: the creation of a stable combination of representative and direct democracy in the arena of public finance.

276. Although only $22.5 \%$ of Germans are religiously active, almost two-thirds are members of a religious organization that levies the church tax. See Sticht, supra note 261. 
